\title{
Status Badan Usaha Milik Desa Sebagai Badan Hukum Atas Diundangkannya Undang-Undang Cipta Kerja
}

\author{
Alfiansyah \\ Magister Ilmu Hukum, Universitas Indonesia \\ Email: alfiansyah.adv@gmail.com
}

\begin{abstract}
Abstrak. Badan Usaha Milik Desa (BUMDes) diharapkan dapat meningkatkan perekonomian dan pelayanan umum kepada masyarakat di desa. Undang-Undang Nomor 6 Tahun 2014 tentang Desa (UU Desa) menyebutkan BUMDes sebagai badan usaha. Badan usaha yang dimaksud tidak ditentukan secara khusus dalam UU Desa. Hal ini menimbulkan berbagai masalah dalam pendirian maupun usaha BUMDes di masyakarat desa. Penelitian ini bertujuan untuk menganalisa status BUMDes sebelum dan sesudah diundangkannya Undang-Undang Nomor 11 Tahun 2020 tentang Cipta Kerja (UU Cipta Kerja) serta implikasinya karena dalam Pasal 117 UU Cipta Kerja mengubah Pasal 1 angka 6 UU Desa yang sebelumnya menyebut BUMDes sebagai badan usaha diubah menjadi badan hukum. Penelitian ini menggunakan metode penelitian doctrinal research. Sumber bahan hukum yang digunakan dalam penelitian ini meliputi bahan-bahan hukum primer, bahan-bahan hukum sekunder serta bahan-bahan hukum tersier dan metode analisis yang digunakan metode analisis dedukatif. Dapat disimpulkan bahwa status BUMDes sebelum diundangkannya UU Cipta Kerja adalah badan usaha yang berbentuk badan hukum karena BUMDes telah memenuhi karakteristik dari badan hukum. Kemudian status badan hukum BUMDes dipertegas dalam UU Cipta Kerja yang membuat BUMDes dapat memiliki sifat seperti badan hukum yang lain pada umumnya dan BUMDes dapat disahkan sebagai badan hukum.
\end{abstract}

Kata Kunci: BUMDes, Badan Usaha, Badan Hukum

Abtract. Village-owned enterprises (BUMDes) are expected to improve the economy and public services to the community in the village. Law Number 6 of 2014 concerning Villages (Village Law) mentions BUMDes as business entities. The business entity in question is not specifically specified in the Village Law. This raises various problems in the establishment and business of BUMDes in the village community.This study aims to analyze the status of BUMDes before and after the enactment of Law Number 11 of 2020 concerning Job Creation (Job Creation Law) and its implications because Article 117 of the Job Creation Law changes Article 1 number 6 of the Village Law which previously mentioned BUMDes as a business entity was changed to become a legal entity. This research uses the doctrinal research method. Sources of legal materials used in this research include primary legal materials, secondary legal materials as well as tertiary legal materials and the analysis method used is the deductive analysis method. It can be concluded that the BUMDes status prior to the promulgation of the Job Creation Law was a business entity in the form of a legal entity because BUMDes has met the characteristics of a legal entity. Then the status of BUMDes legal entities are emphasized in the Job Creation Law which makes BUMDes able to have characteristics like other legal entities in general and BUMDes can be legalized as legal entities.

Keywords: BUMDes, Business Entity, Legal Entity.

\section{PENDAHULUAN}

Pendahuluan Otonomi daerah adalah kewenangan daerah otonom untuk mengatur dan mengurus kepentingan masyarakat setempat menurut prakarsa sendiri berdasarkan aspirasi masyarakat, sesuai dengan peraturan

Jurnal Ilmu Sosial dan Pendidikan perundang-undang. Sedangkan daerah otonom adalah kesatuan masyarakat yang mempunyai batas daerah tertentu yang berwenang mengatur dan mengurus kepentingan masyarakat setempat menurut prakarsa sendiri 
berdasarkan aspirasi masyarakat dalam ikatan Negara Kesatuan Republik Indonesia.

Otonomi daerah yang diberikan untuk daerah tingkat kabupaten dan kota dirasa belum mendukung secara signifikan dalam kemajuan pembangunan nasional karena berbagai hambatan yang salah satu hambatannya yaitu belum meratanya pembangunan di desa-desa yang ada dalam daerah tersebut, maka di rasa perlu otonomi yang lebih luas dan lebih dekat dengan masyarakat. Menjawab permasalahan tersebut, diterbitkan Undang-Undang Nomor 6 Tahun 2014 tentang Desa (UU Desa), yang dimulainya babak baru pembangunan nasional dari satuan pemerintahan paling dekat dengan masyarakat yaitu Desa.

Pemerintah pusat dalam beberapa tahun tahun terakhir berkomitmen dalam mendukung perkembangan desa. Program presiden memberikan dana satu milyar persatu desa sebagai bentuk kepedulian presiden membangun sampai ke tingkat desa. Pembangunan pedesaan memiliki dua tujuan utama yang ingin diraih, yaitu tujuan jangka panjang dan jangka pendek. Tujuan jangka Panjang pembangunan desa adalah peningkatan kesempatan kerja, berusaha, serta peningkatan penghasilan berdasarkan pendekatan bina manusia, bina usaha, dan bina lingkungan.

Desa menurut Pasal 1 angka 1 UU Desa adalah kesatuan masyarakat hukum yang memiliki batas wilayah yang berwenang untuk mengatur dan mengurus urusan pemerintahan, kepentingan masyarakat setempat berdasarkan prakarsa masyarakat, hak asal usul, dan/atau hak tradisional yang diakui dan dihormati dalam sistem pemerintahan Negara Kesatuan Republik Indonesia.

Pemerintahan Desa yang secara struktural tetap berada di bawah kabupaten/kota tetap menjadi bagian pemerintahan daerah kabupaten/kota, namun pengelolaan terhadap desa dilakukan secara mandiri, pemerintah daerah hanya sebagai pengawas dan pembina dalam mencapai tujuan pembangunan daerah melalui pemberdayaan desa. Salah satu upaya pembangunan desa dimulai dengan pembangunan sumberdaya dan keuangan desa agar penyelenggaraan pemerintahan desa dapat terwujud secara mandiri.

Untuk mendukung upaya pembangunan desa, maka keuangan desa menurut Pasal 72 UU Desa dapat bersumber dari berbagai sumber berikut:

a. pendapatan asli Desa terdiri atas hasil usaha, hasil aset, swadaya dan partisipasi, gotong royong, dan lain-lain pendapatan asli Desa;

b. alokasi Anggaran Pendapatan dan Belanja Negara;

c. bagian dari hasil pajak daerah dan retribusi daerah Kabupaten/Kota;

d. alokasi dana Desa yang merupakan bagian dari dana perimbangan yang diterima Kabupaten/Kota;

e. bantuan keuangan dari Anggaran Pendapatan dan Belanja Daerah Provinsi dan Anggaran Pendapatan dan Belanja Daerah Kabupaten/Kota;

f. hibah dan sumbangan yang tidak mengikat dari pihak ketiga; dan

g. lain-lain pendapatan Desa yang sah.

Pendapatan asli desa sebagaimana yang dimaksud huruf a di atas menjadi salah satu sumber keuangan desa yang sangat vital karena dengan penghasilan pendapatan asli desa yang tinggi akan membuat perekonomian desa menjadi lebih baik dan membuat desa menjadi mandiri tanpa harus ketergantungan bantuan dari pemerintah daerah.

Untuk mendukung pendapatan asli desa, maka desa diberi kewenangan untuk membentuk Badan Usaha Milik Desa (BUMDes). BUMDes layaknya Badan Usaha Milik Negara (BUMN) atau Badan Usaha Milik Daerah (BUMD), yaitu suatu perusahaan yang dimiliki oleh pemerintah setempat, dalam hal ini pemerintah desa.

Menurut Maryunani BUMDes didefinisikan sebagai lembaga usaha desa yang dikelola oleh masyarakat dan pemerintahan desa dalam upaya memperkuat perekonomian desa dan membangun kerekatan sosial masyarakat yang dibentuk berdasarkan kebutuhan dan potensi desa.

Pada hakikatnya BUMDes bukan merupakan hal yang baru, BUMDes telah ada 
dan diatur dalam peraturan perundang-undang terkait desa atau pemerintah daerah sebelum UU Desa terbit pada tahun 2014. BUMDes telah dahulu diatur dalam Pasal 213 ayat (1) Undang-Undang Nomor 32 Tahun 2004 tentang Pemerintah Daerah yang saat ini telah diubah dengan Undang-Undang Nomor 23 Tahun 2014 yakni desa dapat mendirikan badan usaha milik desa sesuai dengan kebutuhan dan potensi desa.

UU Desa dan segala peraturan pelaksananya dinilai masih memiliki kelemahan mengenai aturan terkait BUMDes salah satunya tentang jenis badan usaha yang dimiliki oleh BUMDes. Pasal 1 angka 6 UU Desa berbunyi: "Badan Usaha Milik Desa, yang selanjutnya disebut BUM Desa, adalah badan usaha yang seluruh atau sebagian besar modalnya dimiliki oleh Desa melalui penyertaan secara langsung yang berasal dari kekayaan Desa yang dipisahkan guna mengelola aset, jasa pelayanan, dan usaha lainnya untuk sebesar-besarnya kesejahteraan masyarakat Desa."

Dalam Pasal 1 angka 6 tersebut, BUMDes hanya disebut badan usaha yang membuat kedudukan BUMDes tidak kuat seperti badan hukum semacam perseroan terbatas yang membuat BUMDes mengalami kesulitan untuk mendapatkan permodalan dari bank dan kerjasama dengan pihak lain. Masalah lainnya, BUMDes selama ini sulit untuk independent tanpa pengaruh kepala desa atau pemerintah desa. Management di BUMDes dilakukan tunjuk menunjuk, tanpa rekrutment yang profesional. Dengan demikian BUMDes selalu dikaitkan dengan pemilihan kepala desa.

Pemerintah dengan Dewan Perwakilan Rakyat (DPR) pada tahun 2020 membuat Undang-Undang Nomor 11 Tahun 2020 tentang Cipta Kerja (UU Cipta Kerja). UU Cipta kerja mengatur berbagai sektor dan mengubah berbagai pasal dalam berbagai peraturan perundang-undang salah satunya UU Desa. Pasal 117 UU Cipta Kerja mengubah Pasal 1 angka 6 UU Desa yang sebelumnya dalam UU Desa, BUMDes disebut sebagai badan usaha, maka dalam UU Cipta Kerja, BUMDes disebut sebagai badan hukum.
Perubahan tersebut didasari antara lain oleh masalah-masalah yang telah diuraikan sebelumnya dan dengan perubahan tersebut maka akan membuat perubahan status BUMDes serta implikasinya di masyarakat.

\section{Rumusan Masalah}

Adapun rumusan masalah dalam penelitian ini adalah sebagai berikut:

1. Bagaimana status BUMDes sebelum diundangkannya Undang-Undang Cipta Kerja?

2. Bagaimana status badan hukum BUMDes atas diundangkannya Undang-Undang Cipta Kerja?

\section{Tujuan dan Manfaat Penelitian}

\section{Tujuan Penelitian}

Penelitian ini bertujuan untuk mengetahui, menganalisa serta memahami status BUMDes sebelum dan sesudah diundangankannya UU Cipta Kerja.

2. Manfaat Penelitian

Penelitian ini mempunyai manfaat teoritis dan praktis. Secara teoritis penelitian ini diharapkan memberikan kontribusi dalam perkembangan ilmu pengetahuan hukum, terutama bidang hukum ekonomi dan ilmu pengetahuan perundang-undangan. Sedangkan secara praktis, hasil penelitian ini dapat digunakan sebagai sumber kajian ilmu pengetahuan bagi masyarakat terutama pemerintah desa pada umumnya dan kepada akademisi pada khususnya.

\section{METODE PENELITIAN}

Dalam melakukan penelitian, penulis menggunakan metode penelitian doctrinal research yaitu penelitian yang menyediakan ekspos sistematis terhadap peraturan yang mengatur kategori hukum tertentu, menganalisis hubungan antar peraturan, menjelaskan area yang mengalami hambatan dan bahkan memperkirakan perkembangan mendatang.

Sumber bahan hukum yang digunakan dalam penelitian ini meliputi bahan-bahan hukum primer, bahan-bahan hukum sekunder dan bahan-bahan hukum tersier. Bahan hukum primer meliputi peraturan perundangundangan Bahan hukum sekunder meliputi literatur terkait berupa buku, jurnal ilmiah, 
artikel dalam berita, serta artikel dalam internet. Serta bahan hukum tersier yang meliputi kamus-kamus hukum.

Penulis menggunakan metode analisis deduktif yakni metode analisis yang menganalisis sumber hukum yaitu peraturan perundang-undangan serta literatur yang terkait sebagai suatu hal yang umum, kemudian ditarik kesimpulan yang bersifat khusus selanjutnya dibahas, disusun, diuraikan, ditafsirkan serta dikaji permasalahannya untuk mendapatkan gambaran mengenai tingkat sinkronisasi dari semua bahan hukum dan memperoleh kesimpulan sebagai upaya pemecahan masalah.

\section{HASIL DAN PEMBAHASAN}

\section{Status BUMDes Sebelum UU No.11 Tahun 2020 tentang Cipta Kerja}

\section{A. Pengertian Badan Usaha}

Status BUMDes sebagai badan usaha atau badan hukum menjadi sebuah masalah dan perdebatan yang sering terjadi di masyarakat. Hal ini menimbulkan permasalahan ketika BUMDes ingin bekerjasama dengan pihak ketiga ataupun dari independensi BUMDes itu sendiri.

Pasal 1 angka 6 UU Desa menyebutkan BUMDes adalah badan usaha yang seluruh atau sebagian besar modalnya dimiliki oleh desa melalui penyertaan secara langsung yang berasal dari kekayaan desa yang dipisahkan guna mengelola aset, jasa pelayanan, dan usaha lainnya untuk sebesar-besarnya kesejahteraan masyarakat desa dan Pasal 87 ayat (1) UU Desa menyebutkan desa dapat mendirikan Badan Usaha Milik Desa yang disebut BUM Desa. Dalam 2 Pasal tersebut, tidak dijelaskan secara khusus bentuk badan usaha dari BUMDes.

Di Indonesia sendiri terdapat beragam bentuk-bentuk badan usaha baik yang bersifat perorangan, persekutuan maupun badan hukum seperti Perusahaan Dagang (PD), Comanditter Vennootschap (CV), Firma, Persekutuan Perdata (Maatschap), Perseroan Terbatas dan Koperasi. Perseroan Komanditer, Persekutuan Perdata dan Firma adalah badan usaha bukan badan hukum, sedangkan
Perseroan Terbatas dan Koperasi merupakan badan usaha berbadan hukum.

Pada dasarnya bila ditinjau dari sudut status yuridisnya, maka badan usaha itu dapat dibedakan atas:

1) Badan usaha yang termasuk badan hukum, dan

2) Badan usaha yang bukan badan hukum.

Karakteristik dari badan usaha yang termasuk badan hukum adalah subjek hukumnya badan usaha itu sendiri, karena ia telah menjadi badan hukum yang juga termasuk subjek hukum di samping manusia. Pada badan usaha ini harta kekayaan perusahaan terpisah dari harta kekayaan pribadi para pengurus/anggotanya. Akibatnya kalau perusahaannya pailit, yang terkena sita hanyalah harta perusahaannya saja (harta pribadi pengurus/anggotanya tetap bebas dari sitaan).

Karakteristik dari badan usaha yang bukan badan hukum adalah subjek hukumnya adalah adalah orang-orang yang menjadi pengurusnya, jadi bukan badan usaha itu sendiri karena ia bukanlah hukum sehingga tidak dapat menjadi subjek hukum. Pada badan usaha ini harta perusahaan bersatu dengan harta pribadi para pengurus/anggotanya. Akibatnya kalau perusahaannya pailit, harta pribadi pengurus/anggotanya ikut tersita selain harta perusahaannya.

\section{B. Status BUMDes Dalam UU Desa}

Secara historis, pada awalnya BUMDes diatur sebagai badan hukum. Ini dapat dilihat dalam penjelasan Pasal 213 ayat (2) UndangUndang Nomor 32 Tahun 2004 tentang Pemerintah Daerah yaitu Badan Usaha Milik Desa adalah badan hukum sebagaimana diatur dalam peraturan perundang-undangan dan ditegaskan kembali dalam Pasal 78 ayat (3) Peraturan Pemerintah Nomor 72 Tahun 2005 tentang Desa yaitu Bentuk Badan Usaha Milik Desa sebagaimana dimaksud pada ayat (1) harus berbadan hukum.

Sekitar 10 tahun kemudian, dengan disahkannya UU Desa bentuk badan usaha BUMDes berubah. Di dalam Pasal 1 angka 6 UU Desa, disebutkan BUMDes adalah badan usaha dan dalam penjelasannya di Pasal 87 ayat (1) BUMDesa merupakan suatu badan 
usaha bercirikan desa yang secara spesifik tidak bisa disamakan dengan badan hukum seperti perseroan terbatas, $\mathrm{CV}$ atau koperasi. Yang membuat BUMDes menjadi bentuk badan usaha berbadan hukum yang baru. Berbeda dengan BUMN dan BUMD yang dalam peraturan perundang-undangan telah jelas diatur dapat berbentuk perseroan terbatas maupun perseroan umum.

Secara karakteristik, BUMDes telah dapat dikategorikan sebagai badan usaha berbadan hukum karena telah memenuhi karakteristik sebagai berikut:

1. Adanya harta kekayaan terpisah

Pasal 135 ayat (3) Peraturan Pemerintah Republik Indonesia Nomor 47 Tahun 2015 Tentang Perubahan Atas Peraturan Pemerintah Nomor 43 Tahun 2014 menyebutkan bahwa kekayaan BUMDes yang bersumber dari penyertaan modal desa merupakan kekayaan desa yang dipisahkan.

2. Mempunyai tujuan tertentu

Penjelasan Pasal 87 ayat (1) UU Desa menyebutkan bahwa BUMDes dibentuk untuk mendayagunakan segala potensi ekonomi, kelembagaan perekonomian, serta potensi sumber daya alam dan sumber daya manusia dalam rangka meningkatkan kesejahteraan masyarakat desa.

3. Mempunyai kepentingan sendiri

Kepentingan BUMDes terdapat juga dalam Penjelasan Pasal 87 ayat (1) UU Desa menyebutkan bahwa BUMDes berorientasi kepada keuntungan keuangan dan mendukung peningkatan kesejahteraan masyarakat.

4. Adanya organisasi yang teratur Organisasi BUMDes terpisah dari organisasi pemerintah desa dan organisasi BUMDes paling sedikit terdiri atas penasihat serta pelaksana operasional. Ketetuan ini di atur dalam Pasal 132 ayat (3) dan (4) Peraturan Pemerintah Republik Indonesia Nomor 43 Tahun 2014.

\section{Status BUMDes Sebagai Badan Hukum Dalam UU Cipta Kerja \\ A. Pengaturan tentang BUMDes Dalam UU Cipta Kerja}

Pasal 1 angka 1 Undang-Undang Nomor 11 Tahun 2020 tentang Cipta Kerja (UU Cipta Kerja) menjelaskan mengenai definisi cipta kerja yaitu upaya penciptaan kerja melalui usaha kemudahan, perlindungan, dan pemberdayaan koperasi dan usaha mikro, kecil, dan menengah, peningkatan ekosistem investasi dan kemudahan berusaha, dan investasi Pemerintah Pusat dan percepatan proyek strategis nasional.

Tujuan diundangkannya UU Cipta kerja adalah sebagaimana dimuat di dalam bagian konsiderannya. UU Cipta Kerja diharapkan mampu menyerap tenaga kerja Indonesia yang seluas-luasnya di tengah persaingan yang semakin kompetitif dan tuntutan globalisasi ekonomi. Pengaturan yang berkaitan dengan kemudahan, perlindungan, dan pemberdayaan koperasi dan usaha mikro, kecil, dan menengah, peningkatan ekosistem investasi, dan percepatan proyek strategis nasional, termasuk peningkatan perlindungan dan kesejahteraan pekerja yang tersebar di berbagai Undang-Undang sektor saat ini belum dapat memenuhi kebutuhan hukum untuk percepatan cipta kerja sehingga perlu dilakukan perubahan.

Adapun findasan filosofis diundangkannya UU Cipta Kerja adalah didasarkan pada Pasal 4, Pasal 5 ayat (1), Pasal 18, Pasal 18A, Pasal 18B, Pasal 20, Pasal 22D ayat (2), Pasal 27 ayat (2), Pasal 28D ayat (1) dan ayat (2), dan Pasal 33 Undang-Undang Dasar Negara Republik Indonesia Tahun 1945.

Terdapat pengaturan mengenai BUMDes dalam UU Ciptaker sebagaimana diatur dalam Pasal 117 UU Cipta Kerja yang mengubah ketentuan dalam Undang-Undang Nomor 6 Tahun 2014 tentang Desa Pasal 1 angka 6 Badan Usaha Milik Desa, yang selanjutnya disebut BUM Desa, adalah Badan Hukum yang didirikan oleh desa dan/atau bersama desa-desa guna mengelola usaha, memanfaatkan aset, mengembangkan investasi dan produktivitas, menyediakan jasa pelayanan, dan/atau menyediakan jenis usaha lainnya untuk sebesar-besarnya kesejahteraan masyarakat Desa.

Serta Ketentuan Pasal 87 yang juga mengatur tentang BUMDes diubah sehingga berbunyi sebagai berikut:

Pasal 87

(1) Desa dapat mendirikan BUM Desa. 
(2) BUM Desa sebagaimana dimaksud pada ayat (1) dikelola dengan semangat kekeluargaan dan kegotongroyongan.

(3) BUM Desa dapat menjalankan usaha di bidang ekonomi dan/atau pelayanan umum sesuai dengan ketentuan peraturan perundang-undangan.

(4) BUM Desa sebagaimana dimaksud pada ayat (1) dapat membentuk unit usaha berbadan hukum sesuai dengan kebutuhan dan tujuan.

(5) Ketentuan lebih lanjut mengenai BUM Desa sebagaimana dimaksud pada ayat (1), ayat (2), ayat (3), dan ayat (4) diatur dengan Peraturan Pemerintah.

Penjelasan Pasal 117 ayat (1) UU Ciptaker yang mengubah ketentuan dalam Pasal 87 UU Desa menjelaskan bahwa BUM Desa dibentuk oleh Pemerintah Desa untuk mendayagunakan segala potensi ekonomi, kelembagaan perekonomian, serta potensi sumber daya alam dan sumber daya manusia dalam rangka meningkatkan kesejahteraan masyarakat Desa. BUM Desa secara spesifik tidak dapat disamakan dengan badan hukum seperti perseroan terbatas, atau koperasi. Oleh karena itu, BUM Desa merupakan suatu badan usaha bercirikan Desa yang dalam pelaksanaan kegiatannya di samping untuk membantu penyelenggaraan Pemerintahan Desa, juga untuk memenuhi kebutuhan masyarakat Desa. BUM Desa juga dapat melaksanakan fungsi pelayanan jasa, perdagangan, dan pengembangan ekonomi lainnya.

Dalam meningkatkan sumber pendapatan Desa, BUM Desa dapat menghimpun tabungan dalam skala lokal masyarakat Desa, antara lain melalui pengelolaan dana bergulir dan simpan pinjam. BUM Desa dalam kegiatannya tidak hanya berorientasi pada keuntungan keuangan, tetapi juga berorientasi untuk mendukung peningkatan kesejahteraan masyarakat Desa. BUM Desa diharapkan dapat mengembangkan unit usaha dalam mendayagunakan potensi ekonomi. Dalam hal kegiatan usaha dapat berjalan dan berkembang dengan baik, sangat dimungkinkan pada saatnya BUM Desa mengikuti badan hukum yang telah ditetapkan dalam ketentuan peraturan perundangundangan.

\section{B. Implikasi Status Badan Hukum pada BUMDes}

Dalam kepustakaan berbahasa Inggris, istilah badan hukum seringkali disebut dengan istilah-istilah: legal entity, juristic person, atau artificial person. Black's Law Dictionary mendefinisikan artificial person sebagai persons created and devised by human laws for the purposes of society and government, as distinguished from natural person. Sementara legal entity didefinisikan sebagai an entity, other than natural person, who has sufficient existence in legal contemplation that it can function legally, be sued or sue and make decisions through agents as in the case of corporation. Lebih lanjut Black's Law Dictionary, memberikan pengertian legal entity sebagai: (a) body, other than a natural person, that can function legally, sue or be sued, and make decisions thorugh agents. Sedangkan legal person diartikan sebagai an entity such as corporation, created by law given certain legal rights and duties of a human being; a being,real or imaginary, who for the purpose of legal reasoning is treated more or less as a human being

Menurut Utrecht, badan hukum merupakan setiap pendukung hak yang tidak berjiwa atau bukan manusia. Menurut Sudikno Mertokusumo, badan hukum adalah organisasi atau kelompok manusia yang mempunyai tujuan tertentu yang dapat menyandang hak dan kewajiban. Menurut Subekti badan hukum adalah suatu badan atau perkumpulan yang dapat memiliki hakhak melakukan perbuatan seperti seorang manusia, serta memiliki kekayaan sendiri yang dapat digugat atau menggugat di depan hakim.

Badan hukum merupakan suatu badan yang dapat memiliki hak hak dan kewajibankewajiban untuk melakukan perbuatan sendiri. Badan hukum merupakan subyek hukum seperti orang. Syarat agar suatu badan dapat dikategorikan sebagai badan hukum, antara lain; adanya harta kekayaan dengan tujuan tertentu yang terpisah dengan kekayaan 
pribadi para sekutu atau pendiri, kepentingan yang menjadi tujuan adalah kepentingan bersama, adanya beberapa orang sebagai pengurus badan. Badan hukum dapat digolongkan atas dua bagian besar, yaitu badan hukum publik dan badan hukum perdata. Pasal 1653 KUHPerdata menyebutkan bahwa badan hukum dapat diadakan oleh kekuasaan umum; badan hukum yang diakui oleh kekuasaan umum; dan badan hukum yang diperkenankan dan yang didirikan dengan tujuan tertentu, yang tidak bertentangan dengan undangundang atau kesusilaan.

Posisi BUMDes setelah UU Cipta Kerja sebagai Badan Hukum Entitas Baru yang kedudukannya setara dengan Perseroan Terbatas (PT) setara dengan BUMN pada level nasional dan BUMD pada level daerah sebagaimana dijelaskan dalam Penjelasan Pasal 117 UU Cipta Kerja yang mengubah Pasal 787 UU Desa bahwa Posisi BUMDes sebagai badan hukum tidak dapat dipersamakan dengan Perseroan dan Koperasi. Adapun Dampak Positif yang diharapkan atas status BUMDes sebagai badan Hukum meliputi:

1. Mempermudah kemitraan desa

2. Mempermudah mempromosikan potensi daerah

3. Mempercepat perbaikan ekonomi daerah

4. Mempercepat keberhasilan SGDs Nasional

\section{KESIMPULAN}

1. Status BUMDes Sebelum UU Cipta Kerja secara karakteristik, BUMDes telah dapat dikategorikan sebagai badan usaha berbadan hukum karena telah memenuhi karakteristik adanya harta kekayaan terpisah, mempunyai tujuan tertentu, mempunyai kepentingan sendiri dan adanya organisasi yang teratur.

2. BUMDes berbentuk badan hukum sebagaimana diatur dalam UU Cipta Kerja diharapkan menjadi jalan keluar bagi status BUMDes selama ini, sehingga diharapkan berdampak positif bagi perekonomian desa. Selaku badan hukum maka BUMDes juga akan memiliki sifat seperti badan hukum lain pada umumnya yaitu dapat memiliki kekayaan terpisah dan dapat bertindak sebagai rechtpersoon.

\section{SARAN}

1. Adapun saran yang penulis berikan yakni Peraturan Pelaksana terkait BUMDes diharapkan dapat disosialisasikan dengan baik dan merata agar tujuan dari penegasan status badan hukum BUMDes dapat tercapai.

2. BUMDes dapat kemudahan dalam hal melakukan pengesahan sebagai badan hukum agar dapat bertindak sebagai rechtpersoon.

\section{DAFTAR PUSTAKA}

Haw, Widjaja. (2002) Pemerintahan Desa/Marga Berdasarkan UndangUndang Nomor 22 Tahun 1999 tentang Pemeritahann Daerah. Jakarta: PT. Raja Grafindo Persada.

Ismaidar, Agus Adhari. (2017). Analisis Hukum Pembentukan Badan Usaha Milik Desa dalam Upaya Meningkatkan Pendapatan Asli Desa di Kecamatan Babalan Kabupaten Langkat. "Dialogia Iuridica". Vol. 9 No. 1.

Kusuma, Amelia Sri. (2010). Alternatif Bentuk Badan Hukum yang Tepat dalam Pendirian Badan Usaha Milik Desa (BUMDes) sebagai Upaya Meningkatkan Pendapatan Asli Desa (PADes), "Pamator", Vol. 3 No. 1.

Mahmud Marzuki, Peter. Penelitian Hukum. Jakarta: Prenadamedia.

Maryunani, Pembangunan Bumdes dan Pemerdayaan Pemerintah Desa. Bandung: CV Pustaka Setia.

Muhammad, Abdulkadir. Hukum Perusahaan Indonesia, Bandung: PT. Citra Aditya Bhakti.

Sugiayanto. (2017). Urgensi dan Kemandirian Desa dalam Presfektif UndangUndang No 6 Tahun 2014. Deepublish.

Suparji. (2014). Transformasi Badan Hukum Di Indonesia. Suparji. Jakarta: Fakultas Hukum Universitas Al Azhar Indonesia. 
Jurnal Ilmu Sosial dan Pendidikan

Vol. 5. No. 2 Maret 2021

http://ejournal.mandalanursa.org/index.php/JISIP/index

Terakreditasi Peringkat 5 (No. SK: 85/M/KPT/2020)

p-ISSN: 2598-9944 e- ISSN: 2656-6753

$\mathrm{T}$, Kumolo. Integrasi Perencanaan Pembangunan Nasional dan Daerah. Jakarta: PT. Gramedia.

Undang-Undang Nomor 11 Tahun 2020 tentang Cipta Kerja.

Undang-Undang Nomor 6 Tahun 2014 tentang Desa. 